\title{
The Evaluation of Healthcare Associated Bloodstream Infections at a Tertiary Care Hospital Between 2011 and 2015: Epidemiology and Mortality Risk Factors
} Üçünü Basamak Bir Hastanede, 2011-2015 Yılları Arasındaki Sağlık Bakım Ilișkili Kan Dolașımı Enfeksiyonlarının Değerlendirilmesi; Epidemiyoloji ve Mortalite Risk Faktörleri

\author{
Aliye Baștuğ ${ }^{1}$, Esragül Akıncı', Adalet Aypak, Dilek Kanyılmaz², Halide Aslaner ${ }^{1}$, Ayșe But', \\ Meltem Arzu Yetkin', Pınar Öngürü1, Hürrem Bodur' \\ ${ }^{1}$ Ankara Numune Training and Research Hospital, Department of Infectious Diseases and Clinical Microbiology; ${ }^{2}$ Infection Control \\ Committee, Ankara, Turkey
}

\begin{abstract}
Aim: Bloodstream infections (BS/s) are an important cause of mortality in hospitals. Local surveillance data should be taken into account to overcome these challenging infections. The aim of this study is to determine the microbiological characteristics of BS/s and the risk factors for mortality.

Material and Method: Active prospective surveillance data based on patient and laboratory were evaluated from January 2011 to June 2015. The first episodes of primary BSIs of the patients were included to the study. CDC case definitions were used to define $B S / s$. The data were recorded included demographics, underlying conditions, invasive procedures, fever $\left(>=38^{\circ} \mathrm{C}\right)$ or hypothermia $\left(<36^{\circ} \mathrm{C}\right)$, causative isolates and antimicrobial resistance patterns, appropriate antimicrobial therapy within 3 days after the onset of infection and outcome on day 14 after infection onset.

Results: During the study period 373 patients with health care associated BSIs were identified. Acinetobacter spp. was the most common isolate $(20.4 \%, n=76)$, followed by Coagulase negative Staphylocccus (CoNS) (19.3\%, $n=72)$, Candida spp. (17.2\%, $n=64)$ and Klebsiella spp. $(11 \%, n=41)$, respectively. Multidrug resistance ratio was $98.7 \%$ for Acinetobacter spp. Methicillin resistance was found $66.7 \%$ of Staphylococcus aureus (S.aureus) and $79.2 \%$ of CoNS. Extended spectrum beta lactamases (ESBL) ratio for Klebsiella spp. was 65\% (26/40) and 67.9\% (19/28) for E.coli. The mortality rate of the patients in the first 14 days was $37.8 \%(n=141)$. Logistic regression analysis re-vealed that, BS/s due to the Acinetobacter spp. and Candida spp. had 2.35 and 2.48 times higher mortality rates, respectively. Inappropriate antimicrobial therapy, presence of hypothermia, steroid usage, dialysis and presence of two or more underlying conditions were other independent predictors for mortality.
\end{abstract}

Conclusion: It is important to perform active surveillance for $B S / s$ which result in high mortality rates due to resistant isolates. Appropriate antimicrobial therapy is crucial since it has a significant impact to decrease mortality.

Key words: bloodstream infections; mortality predictors; epidemiology

Aliye Baștŭ̆, Ankara Numune Research and Training Hospital Altındăg, Ankara, Türkiye, Tel.03125084832Email.draliye@yahoo.com

Geliş Tarihi: 09.09.2015 • Kabul Taribi: 22.12.2015
ÖZET

Amaç: Kan dolașımı enfeksiyonları (KDE) hastanelerde mortalitenin önemli nedenlerindendir. Bu enfeksiyonları yönetebilmek için lokal surveyans verileri göz önünde bulundurulmalıdır. Bu çalıșmanın amacı; kan dolașımı enfeksiyonlarında mikrobiyolojik karakteristikleri ve mortalite risk faktörlerini belirlemektir.

Materyal ve Metot: Ocak 2011 ve Haziran 2015 yılları arası hasta ve laboratuvara dayalı aktif prospektif surveyans verileri değerlendirildi. Çalıșmaya primer kan dolașımı enfeksiyonu olan hastaların ilk epizodları dahil edildi. Kan dolașımı enfeksiyonlarını tanımlamak için CDC tanı kriterleri kullanıldı. Kaydedilen veriler arasında; demografik veriler, altta yatan hastalıklar, invaziv ișlemler, ateș $\left(\geq 38^{\circ} \mathrm{C}\right)$ veya hipotermi $\left(<36^{\circ} \mathrm{C}\right)$ varığı, etken izolatlar ve antimikrobiyal direnç paternleri, hastalığın bașlangıcı sonrası ilk 3 gün içinde uygun antibiyotik kullanımı ile 14 gün içindeki mortalite yer almaktadır.

Bulgular: Çalıșma süresince sağlık bakım ilișkili kan dolașımı enfeksiyonu olan 373 hasta tanımlandı. Acinetobacter en sık saptanan izolat $(\% 20,4, n=76)$ olup sonrasında sırasıly Koagulaz negatif stafilokoklar (KNS) (\%19,3, n=72), kandida sușları (\%17,2, $n=64)$ ve Klebsiella sușları $(\% 11, n=41)$ saptandı. Acinetobacter sușları arasında çok ilaca direnç oranı \%98,7 idi. Metisilin direnci S.aureus için \%66,7 ve KNS için \%79,2 bulundu. Genișlemiș spektrumlu beta laktamaz (ESBL) oranı Klebsiella sușlarında \%65 (25/40) ve E.coli sușlarında \%67,9 (19/28) idi. Hastalarda ilk 14 gün içindeki mortalite oranı \%37,8 $(n=141)$ idi. Lojistik regresyon analizi sonucunda; acinetobacter ve kandida izolatlarına bağı kan dolașımı enfeksiyonlarında sırasıyla 2,35 ve 2,48 kat daha fazla mortalite oranı saptandı. Uygun olmayan antibiyotik tedavisi, hipotermi varlığı, steroid kullanımı, diyaliz ve iki veya daha fazla altta yatan hastalık olması mortaliteyi gösteren diğer bağımsız faktörler olarak bulundu.

Sonuç: Dirençli izolatlara bağlı olușan kan dolașımı enfeksiyonları yüksek mortalite ile sonuçlandığından bu enfeksiyonlar için aktif surveyans yapılması önemlidir. Uygun antimikrobiyal tedavi mortaliteyi anlamıl olarak azalttığından oldukça önemlidir.

Anahtar kelimeler: kan dolașımı enfeksiyonlarl; mortalite prediktörleri; epidemiyoloji 


\section{Introduction}

Bloodstream infections (BSIs) are one of the major health care associated infections in nosocomial setting and associated with significant morbidity and mortality. The causative microorganisms and resistance patterns of isolates vary in different setting and geographic regions ${ }^{1,2}$. In addition, increasing rate of the resistant microorganisms further complicate the problem and increase the mortality rate. For that reason, it is important to monitor the most frequent isolates and determine their resistance patterns since the early appropriate antimicrobial therapy is crucial to decrease the mortality. Therefore, the performance of active prospective surveillance and careful evaluation of the data regarding these infections are important ${ }^{1-3}$.

The aim of this study was to evaluate the current epidemiology, isolate distribution and resistance patterns of causative microorganisms, in addition to the mortality risk factors and 14-day outcome after the onset of BSIs.

\section{Material and Method}

\section{Patients and Hospital Settings}

The present study was conducted in Ankara Numune Training and Research Hospital (ANTRH) in Turkey. Active prospective surveillance data based on patient and laboratory were evaluated from January 2011 to June 2015 in the 1140-bed tertiary care hospital. The data was gathered by the nurses working in infection control committee and infectious disease specialists. The criteria of Centers for Disease Control and
Prevention (CDC) case definition was used to define BSIs. The first episode of primary BSIs of the patients $\geq 18$ years from intensive care units and wards were included into the study. However, the patients with polymicrobial BSIs were excluded.

\section{Data Collection}

The data including; demographic characteristics, intensive care unit (ICU) stay, underlying conditions (e.g., diabetes mellitus, chronic renal failure, chronic obstructive pulmonary disease (COPD), invasive procedures (central venous catheter (CVC), mechanical ventilator (MV) etc.), support of total parenteral nutrition (TPN), fever $\left(>=38^{\circ} \mathrm{C}\right)$ or hypothermia $\left(<36^{\circ} \mathrm{C}\right)$, BSI type (CVC related or not), causative isolates and antimicrobial resistance patterns (Multidrug resistance (MDR), extended spectrum beta lactamases (ESBL), methicillin resistance), appropriate antimicrobial therapy within 3 days after the onset of infection, and 14day outcome after the onset of infection were recorded.

\section{Definitions}

Definitions were provided in Table 1 based on the previous studies and guidelines ${ }^{3-5}$.

\section{Microbiological Tests}

Isolate identification and antimicrobial susceptibility tests were performed using a VITEK automated system BioMerieux, Marcy I'Etoile, France). The Clinical and Laboratory Standards Institute (CLSI) criteria were used to determine the resistance or susceptibility

Table 1. Definitions

Laboratory-confirmed bloodstream infection (LCBI) ${ }^{3}$

Laboratory-confirmed central venous catheter-associated bloodstream infections (CVC-BSI) ${ }^{3}$

Multidrug resistant bacteria infection ${ }^{4}$

Appropriate antimicrobial therapy ${ }^{5}$
Patients with at least has one of the following criteria;

1) Isolation of microorganisms from blood (such as E.coli, Klebsiella spp., Pseudomonas spp., S.aureus, Enterococcus spp., Candida spp, and others) for $\geq 1$ positive culture that was not related to another infection of body sites

2) Patients with one of the following signs that was not related to another infection focus; fever $\left(38^{\circ} \mathrm{C}\right)$, chills or hypotension and $\geq 2$ positive different culture results for probable skin contaminant pathogens, such as Coagulase negative Staphylococcus (CoNs)

Patients with a CVC had a recognized pathogen isolated from $\geq 1$ percutaneous blood cultures after $48 \mathrm{~h}$ of central venous catheterization (unrelated with another infection). The patients should also have at least one of the following signs and symptoms: fever $\left(38^{\circ} \mathrm{C}\right)$, chills, or hypotension. With the common skin commensals (e.g., diphtheroids, (CoNs)), the organisms had to have been cultured from $\geq 2$ separate blood cultures

An infection due to a Gram-negative bacteria which has a resistance to $\geq 3$ classes of antimicrobial agents

Administrated drug has in-vitro activity against the causative isolates according to antimicrobial susceptibility test results or administration of the drug within $72 \mathrm{~h}$ of the infection onset

Death within 14 days of infection onset 
to the antimicrobial agents ${ }^{6}$. ESBL production was determined and confirmed using a double-disc synergy test in line with CLSI guidelines ${ }^{7}$.

Variables such as demographic characteristics, etiologic agents, antimicrobial resistance patterns of the isolates, inappropriate antimicrobial therapy and all other possible causes of mortality were identified. Survivors and non-survivors 14 days after the onset of BSI were compared to identify the predictors of the mortality. Continuous variables were described as median (min$\max$ ). Chi-square tests were used for categorical variables and Mann Whitney $U$ tests were used for continued variables. The variables found to be significantly associated with mortality in the univariate analysis were included in Logistic regression analysis. $p$ values $<0.05$ were considered statistically significant. Odds ratios and
95\% confidence intervals (95\% CI) were calculated. Statistical analysis was performed using SPSS 18.0.

\section{Results}

A total of 373 patients with health care associated BSIs were enrolled in the study, including 199 (53.4\%) men. The median age was 62 (18-97 years). Of 373 patients, 252 were from intensive care units, 260 (69.7\%) had one underlying condition, and 94 (25.2\%) had $\geq 2$ underlying condition. The predominant underlying condition was malignancy that was found in the $30.3 \%$ of the patients. Catheter related BSI was determined in $292(78.5 \%)$ patients. Length of time to emergence of BSI was median 20 days (3-141 days). Fever $\left(>38^{\circ} \mathrm{C}\right)$ was present in $63.5 \%$ of the patients (Table 2). Majority of the cultivated pathogens were

Table 2. Basal characteristics of the patients

\begin{tabular}{|c|c|c|c|c|}
\hline Characteristics & $\begin{array}{c}\text { Number of patients } \\
\mathrm{n}(\%)\end{array}$ & $\begin{array}{c}\text { Survivors } \\
(n=232) n(\%)\end{array}$ & $\begin{array}{l}\text { Non-survivor } \\
(n=141) n(\%)\end{array}$ & $\begin{array}{c}\mathrm{P} \\
\text { value }\end{array}$ \\
\hline Age (median, min-max years) & $62(18-97)$ & $56(18-97)$ & $68(19-64)$ & 0.000 \\
\hline Age $>65$ years & $167(44.8)$ & $85(36.6)$ & $82(58.2)$ & 0.000 \\
\hline Gender (male) & $199(53.4)$ & $132(56.9)$ & $67(47.5)$ & $>0.05$ \\
\hline ICU stay at the time of infection & $252(67.6)$ & $142(61.2)$ & $110(78.0)$ & 0.001 \\
\hline Central venous catheter related BSI & $292(78.3)$ & $182(78.8)$ & $110(78)$ & $>0.05$ \\
\hline Underlying conditions & $260(69.7)$ & $148(63.8)$ & $112(79.4)$ & 0.002 \\
\hline Diabetes mellitus & $45(12.1)$ & $21(9.1)$ & $24(17)$ & 0.032 \\
\hline COPD & $24(6.4)$ & $11(4.8)$ & $13(9.2)$ & $>0.05$ \\
\hline Renal failure & $80(21.4)$ & 37 (15.9) & $43(30.5)$ & 0.001 \\
\hline Hypertension & $55(14.7)$ & $22(9.5)$ & $33(23.4)$ & 0.000 \\
\hline Congestive heart failure & $15(4.0)$ & $6(2.6)$ & $9(6.4)$ & $>0.05$ \\
\hline Serebrovascular disease & $42(11.3)$ & $25(10.8)$ & $17(12.1)$ & $>0.05$ \\
\hline$\geq 2$ underlying conditions & $94(25.2)$ & $43(18.5)$ & $51(36.2)$ & 0.000 \\
\hline Malignancy & $113(30.3)$ & $77(33.5)$ & $36(25.5)$ & $>0.05$ \\
\hline Steroid usage & $44(11.8)$ & $24(17.0)$ & $20(8.6)$ & 0.020 \\
\hline Mechanical ventilator & $197(52.8)$ & $112(48.3)$ & $85(60.3)$ & 0.025 \\
\hline Dialysis & 74 (19.8) & $34(14.7)$ & $40(28.4)$ & 0.002 \\
\hline CVC & $317(85.0)$ & $199(85.8)$ & $118(83.7)$ & $>0.05$ \\
\hline TPN & $113(30.3)$ & $64(27.6)$ & 49 (34.8) & $>0.05$ \\
\hline Fever $\left(>38^{\circ} \mathrm{C}\right)$ & $237(63.5)$ & $147(63.4)$ & $90(63.8)$ & $>0.05$ \\
\hline Hypotermia $\left(<36^{\circ} \mathrm{C}\right)$ & $13(3.5)$ & $4(1.7)$ & $9(6.4)$ & 0.022 \\
\hline Presence of concurrent other infection & $87(23.3)$ & $49(21.1)$ & $38(27.0)$ & $>0.05$ \\
\hline Prior antibiotic therapy ( $>7$ days, before the diagnosis of $\mathrm{BSI}$ ) & $229(61.4)$ & $127(54.7)$ & $102(72.3)$ & 0.001 \\
\hline Inappropriate antimicrobial therapy & $158(42.4)$ & $71(30.6)$ & $87(61.7)$ & 0.000 \\
\hline Length of time to appropriate antimicrobial therapy (median, min-max days) & $0(0-3)$ & $0(0-3)$ & $0(0-3)$ & $>0.05$ \\
\hline Length of time to infection (median, min-max days) & $20(3-141)$ & $20(3-141)$ & $20(3-131)$ & $>0.05$ \\
\hline Central venous Catheterization time prior to infection (median, min-max days) & $14(0-64)$ & $13(0-64)$ & $14.5(2-49)$ & $>0.05$ \\
\hline
\end{tabular}

${ }^{*} \mathrm{COPD}$ : Chronic obstructive pulmonary disease, CVC: central venous catheter, TPN: total parenteral nutrition 
Gram-negative bacteria $(48.5 \%, \mathrm{n}=181)$. Acinetobacter spp. was the most common isolates $(20.4 \%, \mathrm{n}=76)$, followed by $\operatorname{CoNS}(19.3 \%, \mathrm{n}=72)$, Candida spp. (17.2\%, $\mathrm{n}=64)$ and Klebsiella spp. $(11 \%, \mathrm{n}=41)$ (Table 3). When the causative isolates were compared between years 2014 and 2011, a significant decrease in the frequency of Acinetobacter spp. (15.6\%, 15/96 vs 30.1\%, $19 / 63$, respectively $\mathrm{p}=0.016$ ) was detected. There was no other significant difference between years according to other pathogens.

Of total Acinetobacter spp. isolates, the ratio of multidrug resistance was $98.7 \%$. Methicillin resistance was found in $66.7 \%$ of S.aureus and $79.2 \%$ of CoNS. ESBL ratio was $65 \%$ (26/40) for Klebsiella spp. and 67.9\% (19/28) for E.coli. The frequency of resistance (\%) to the main antimicrobial classes among the most prevalent isolates was summarized in Table 4. Empirical antibiotic therapy was applied in $76.9 \%$ of the patients. Inappropriate antimicrobial therapy was determined in $42.4 \%(n=158)$ of the patients, and it was significantly higher in fatal cases $(61.7 \%)$. In addition it was defined as an independent predictor of mortality ( $\mathrm{p}=0.000$, OR: $3.81,95 \%$ CI: 2.2-6.3) (Table 5). The median length of time to appropriate antimicrobial therapy was $0(0-3)$ day and there was no statistical difference between fatal and nonfatal groups. The mortality rate of the patients 14 days after BSIs was $37.8 \%(n=141)$. When the risk factors for mortality were evaluated in univariate analysis, older age ( $>65$ years), ICU stay on the time of infection onset, presence of underlying condition, steroid usage, dialysis, hypothermia, inappropriate antimicrobial therapy, infections due to Acinetobacter spp. and Candida spp. were found as a significant risk factors for mortality (Table 2 and 3). Logistic regression analysis revealed that, BSIs due to the Acinetobacter spp. and Candida spp. had 2.35 and 2.48 times higher mortality rates, respectively. Inappropriate antimicrobial therapy, presence of hypothermia, steroid usage, dialysis and two or more underlying conditions were other independent predictors for mortality (Table 5).

\section{Discussion}

Bloodstream infections are the important causes of morbidity and mortality in nosocomial setting. Prevalence of BSIs, causative isolates and resistance patterns are different across the world ${ }^{8}$. For this reason, surveillance data should be evaluated carefully in order to start appropriate empirical antimicrobial therapy. There are different reports about the frequency of nosocomial infections.
Although, bacteremia is reported as second frequent infections in ICU in some studies, it was reported as a most common health care associated infection in a multicenter study performed in our country ${ }^{9-12}$. It is an important health care problem, since it is frequent and many of the causative microorganisms have developed resistance to the most of the antimicrobials ${ }^{13}$. The present study focused on the identification of the epidemiologic characteristics and antimicrobial resistance patterns (ESBL, MDR etc.) of causative isolates and the predictors of mortality in patients with BSI. We determined the 14 day mortality rate as the main outcome measure and the mortality rate was detected as $37.8 \%$. The median age was significantly higher in fatal cases (68 years) in univariate analysis which was not found as an independent predictor for mortality. Cevik et al. reported that, although statistically insignificant, patient with older age ( $\geq 70$ years) had higher mortality rate ${ }^{14}$ We evaluated the impact of underlying conditions on mortality, since the host defenses have an important role in patient outcome. The presence of $\geq 2$ underlying conditions was detected as a significant risk factor for mortality $(\mathrm{p}=0.018$, OR: 1.98, 95\% CI: $1.1-3.4$ ) consistent with the literature ${ }^{10}$. Hypothermia, dialysis and steroid usage were also found as independent predictors of mortality.

When we evaluated causative microorganisms, we determined that Gram negative pathogens were the most common isolates different from the study of Inan et al., who reported S.aureus as a predominant pathogen in CVC related BSI in ICU ${ }^{1}$. The prevalent pathogen was Acinetobacter spp. (20.4\%), followed by CoNS and Candida spp. in our study. C.albicans is the most common subspecies in Candida spp. consistent with the literature $^{15}$. Higher mortality rates in Gram-negative BSIs were reported in previous studies than Gram-positive infections ${ }^{16,17}$. In the present study, similar with the literature, we demonstrated that infections with Gramnegative isolates had significantly higher whereas infections with Gram-positive isolates had significantly lower mortality rates. We thought that the low virulence of CoNS isolates may be the cause of lower mortality rates. BSIs with Acinetobacter spp. and Candida spp. were determined as independent predictors of mortality. In recent years, there has been a noticeable increase in health care associated infections caused by multidrug resistant pathogens $s^{1,18}$. Wide spectrum antibiotic usage ( $>7$ days) prior to the onset of BSI was found in $61.4 \%$ of all patients, which may be one of the causes of high resistance rate in our study. It is known that, previous antibiotic usage leads to the selection of resistance pathogens ${ }^{19}$. 
Table 3. Distribution of the causative isolates

\begin{tabular}{|c|c|c|c|c|}
\hline Microbial species & $\begin{array}{c}\text { Total } n(\%) \\
(\mathrm{n}=373)\end{array}$ & $\begin{array}{c}\text { Survivors } \\
(n=232)\end{array}$ & $\begin{array}{c}\text { Non-Survivor } \\
(n=141)\end{array}$ & $\begin{array}{c}\mathrm{P} \\
\text { value }\end{array}$ \\
\hline Gram-negative bacteria & $181(48.5)$ & $101(43.5)$ & $80(56.7)$ & 0.007 \\
\hline Escherichia coli & $29(7.8)$ & $20(8.6)$ & $9(6.4)$ & $>0.05$ \\
\hline Klebsiella spp. & $41(11.0)$ & $22(9.5)$ & $19(13.5)$ & $>0.05$ \\
\hline Acinetobacter spp. & $76(20.4)$ & $33(14.2)$ & $43(30.5)$ & 0.000 \\
\hline Other Gram negatives & $35(9.3)$ & $25(10.8)$ & $9(6.3)$ & - \\
\hline Gram-positive bacteria & $128(34.3)$ & $100(43.1)$ & $28(19.9)$ & 0.000 \\
\hline Coagulase negative staphylococci & $72(19.3)$ & $60(25.9)$ & $12(8.5)$ & 0.000 \\
\hline Stapylococcus aureus & $28(7.5)$ & $18(7.7)$ & $10(7.0)$ & $>0.05$ \\
\hline Other Gram positives & $28(7.5)$ & $22(9.5)$ & $6(4.2)$ & - \\
\hline Candida spp. & $64(17.2)$ & $31(13.4)$ & $33(23.4)$ & 0.007 \\
\hline C.albicans & $39(10.5)$ & $19(8.2)$ & 20 (14.2) & $>0.05$ \\
\hline C.nonalbicans & $25(6.7)$ & $12(5.2)$ & $13(9.2)$ & $>0.05$ \\
\hline
\end{tabular}

Table 4. Frequency of resistance (\%) to the main antibiotics among the most prevalent causatives

\begin{tabular}{|c|c|c|c|c|c|c|c|c|c|c|c|}
\hline Species (n) & CAZ/ CRO & IMP/ MEM & AK/ GEN & CIP/ LEV & TZP & COLI & TIGE & ESBL & MDR & OXA & VAN/ TEIC \\
\hline E.coli (28) & 69 & 69 & 13.8 & 65.5 & 42.9 & 0 & 0 & 67.9 & 41.7 & - & - \\
\hline Klebsiella spp. (41) & 68.3 & 94.7 & 61.8 & 66.7 & 71.8 & 0 & 0 & 65 & 60.5 & - & - \\
\hline Acinetobacter spp. (76) & 98.7 & 94.7 & 61.8 & 96.1 & 97.4 & 2.6 & 50 & - & 98.7 & - & - \\
\hline CoNs (72) & - & - & - & - & - & - & - & - & - & 79.2 & 0 \\
\hline S.aureus (28) & - & - & - & - & - & - & - & - & - & 66.7 & 0 \\
\hline
\end{tabular}

CAZ: ceftazidime, CRO: ceftriaxone, IMP: imipenem, MEM: meropenem, AK: Amikacin, GEN: gentamycin, CIP: ciprofloxacin, LEV: levofloxacin, TZP: piperacillin-tazobactam, COLI: colimycin, TIGE: tigecycline, ESBL: extended spectrum beta lactamases, MDR: multi-drug resistance, OXA: oxacillin, VAN: vancomycin, TEIC: teicoplanin

Table 5. Independent predictors of mortality for patients with health care associated BSIs

\begin{tabular}{lccc}
\hline Independent variables & P value & OR & $95 \% \mathrm{Cl}$ \\
\hline Acinetobacter spp. & 0.006 & 2.35 & $1.3-4.3$ \\
Candida spp. & 0.005 & 2.48 & $1.3-4.7$ \\
Inappropriate antimicrobial therapy & 0.000 & 3.81 & $2.2-6.3$ \\
$\geq 2$ underlying condition & 0.018 & 1.98 & $1.1-3.4$ \\
Steroid usage & 0.040 & 2.14 & $1.0-4.4$ \\
Hypothermia & 0.011 & 5.34 & $1.4-19.5$ \\
Dialysis & 0.011 & 2.26 & $1.2-4.2$ \\
\hline
\end{tabular}

Methicillin resistance was found $66.7 \%$ for S.aureus and $79.2 \%$ for CoNS. Inan et al. reported higher MRSA ratio (93.1\%) previously ${ }^{1}$. ESBL comprised $67.9 \%$ of E.coli and $65 \%$ of Klebsiella spp., which were higher than the previous multicenter study in Turkey ${ }^{18}$. In addition, Acinetobacter spp. was usually resistant to the most of the antibiotics used empirically. In fact, multidrug resistance (MDR) rate of Acinetobacter spp. was $98.7 \%$ and carbapenem resistance was $94.7 \%$, which is higher than the previous report of Yüce et al. ${ }^{20}$. We thought that invasive characteristics and resistance patterns of the Acinetobacter spp. had an impact on increased mortality rates. Since the MDR pattern reduces the count of effective antibiotic options, it is frequently related with poor outcome $^{21}$. Appropriate antimicrobial therapy is crucial and is known to have a significant influence on decreasing the mortality of patients with BSI. In the present study, inappropriate antimicrobial therapy was determined as an independent predictor for mortality similar to previous studies ${ }^{15,22}$. In conclusion, we found that 
infections due to the Acinetobacter spp. were predominant in patients with BSI. Because of the emergence of MDR isolates, it is becoming a clinical challenge to overcome these infections. Surveillance data should be evaluated carefully in nosocomial settings. The prevalent isolates and resistance patterns should be taken into account before starting empirical antimicrobial therapy, which is crucial to reduce mortality rate.

\section{References}

1. Freid VM, Prager K, MacKay AP, et al. Health, United States, 2003. Hyattsville, Maryland: National Center for Health Statistics.

2. National Nosocomial Infections Surveillance (NNIS) system report, data summary from January 1992 - April 2000. Am J Infect Control 2000;28:429-48.

3. Wisplinghoff $\mathrm{H}$, Bischoff $\mathrm{T}$, Tallent SM, et al. Nosocomial bloodstream infections in US hospitals: analysis of 24, 179 cases from a prospective nationwide surveillance study. Clin Infect Dis 2004;39:309-17.

4. Warren DK, Zack JE, Elward AM, et al. Nosocomial primary bloodstream infections in intensive care unit patients in a nonteaching community medical center: a 21 - month prospective study. Clin Infect Dis 2001;33:1329-35.

5. DiGiovine B, Chenoweth $\mathrm{C}$, Watts $\mathrm{C}$, et al. The attributable mortality and costs of primary nosocomial bloodstream infections in the intensive care unit. Am J Respir Crit Care Med 1999;160:976-81.

6. Pittet D, Tarara D, Wenzel RP. Nosocomial bloodstream infection in critically ill patients. Excess length of stay, extra costs, and attributable mortality. JAMA 1994;271:1598601.

7. Inan A, Ozgultekin A, Akcay SS, et al. Alterations in bacterial spectrum and increasing resistance rates in isolated microorganisms from device-associated infections in an intensive care unit of a teaching hospital in Istanbul(2004-2010). Jpn J Infect Dis 2012;65:146-51.

8. Edwards JR, Peterson KD, Mu Y, et al. National Healthcare Safety Network (NHSN) report: data summary for 2006 through 2008. Am J Infect Control 2009;37:783-805.

9. Horan TC, Andrus M, Dudeck MA. CDC/NHSN surveillance definition of health care-associated infection and criteria for specific types of infections in the acute care setting. Am J Infect Control 2008;36:309-32.

10. Magiorakos AP, Srinivasan A, Carey RB, et al. Multidrugresistant, extensively drug-resistant and pandrug-resistant bacteria: an international expert proposal for interim standard definitions for acquired resistance. Clin Microbiol Infect 2012;18:268-81.

11. Trecarichi EM, Tumbarello M, Spanu T, et al. Incidence and clinical impact of extended-spectrum-beta-lactamase (ESBL) production and fluoroquinolone resistance in bloodstream infections caused by Escherichia coli in patients with hematological malignancies. J Infect 2009;58:299-307.
12. Clinical and Laboratory Standards Institute Methods for Dilution Antimicrobial Susceptibility Tests for Bacteria that grow aerobically, 2009; 8th Edition: Approved Standard M07-A8. CLSI, Wayne, PA, USA.

13. Clinical and Laboratory Standards Institute Performance Standards for Antimicrobial Susceptibility Testing: Twentieth Informational Supplement 2010;M100-S20. CLSI, Wayne, PA, USA.

14. Zenebe T, Kannan S, Yilma D, et al. Invasive Bacterial Pathogens and their Antibiotic Susceptibility Patterns in Jimma University Specialized Hospital, Jimma, Southwest Ethiopia. Ethiop J Health Sci 2011;21:1-8.

15. Öncül A, Koçulu S, Elevli K. Bir devlet hastanesinin yoğun bakım ünitelerinde kazanılan hastane enfeksiyonlarının epidemiyolojisi. Şişli Etfal Hast Tıp Bül 2012;46:60-6.

16. Meric M, Baykara N, Aksoy S, et al. Epidemiology and risk factors of intensive care unit acquired infections: a prospective multicentre cohort study in a middle-income country. Singapore Med J 2012;53:260-3.

17. Göktaş U, Yaman G, Karahocagil MK, et al. Anestezi yoğun bakım ünitesinde hastane enfeksiyonu etkenleri ve direnç profilinin değerlendirilmesi. J Turk Soc Int Care Med 2010;8:13-7.

18. Şardan YÇ, Aş̧̧ı̆ı̆lu S, Büke Ç et al. Yoğun bakım ünitelerinde hastane infeksiyonlarının prevalansı: Çok merkezli bir nokta prevalans çalışması. Hast İnf Derg 2006;10:33.

19. Joann D. Antibiotic resistance: the ongoing challenge for effective drug therapy. JAAPA 2009;22:18-22.

20. Çevik MA, Yılmaz GR, Erdinç FŞ, et al. Nöroloji Yoğun Bakım Ünitesinde Mortalite ile İlişkili Faktörler ve Nozokomiyal İnfeksiyonla Mortalitenin İlişkisi. Yoğun Bakım Derg 2001;1:47-55.

21. Bassetti M, Merelli M, Ansaldi F, et al. Clinical and therapeutic aspects of candidemia: a five year single centre study. PLoS One 2015.

22. Horasan ES, Ersoz G, Tombak A, et al. Bloodstream infections and mortality-related factors in febrile neutropenic cancer patients. Med Sci Monit 2011;17:304-9.

23. Tumbarello M, Spanu T, Caira M, et al. Factors associated with mortality in bacteremic patients with hematologic malignancies. Diagn Microbiol Infect Dis 2009;64:320-6.

24. Gür D, Hascelik G, Aydın N, et al. Antimicrobial resistance in gram - negative hospital isolates: results of the Turkish HITIT-2 Surveillance Study of 2007. JChemother 2009;21:383-9.

25. Lorente C, Del Castillo Y, Rello J. Prevention of infection in the intensive care unit: current advances and opportunities for the future. Curr Opin Crit Care 2002;8:461-4.

26. Yüce A, Yapar N, Eren Kutsoylu O. Evaluation of antibiotic resistance patterns of Pseudomonas aeruginosa and Acinetobacter spp. strains isolated from intensive care patients between 20002002 and 2003-2006 periods in Dokuz Eylul University Hospital, İzmir. Mikrobiyol Bul 2009; 43:195-202.

27. Trecarichi EM, Tumbarello M. Antimicrobial-resistant Gramnegative bacteria in febrile neutropenic patients with cancer: current epidemiology and clinical impact. Curr Opin Infect Dis 2014;27:200-10.

28. Montassier E, Batard E, Gastinne T, et al. Recent changes in bacteremia in patients with cancer: a systematic review of epidemiology and antibiotic resistance. Eur J Clin Microbiol Infect Dis 2013;32:841-50. 